\title{
ON OESOPHAGOSTOMUM APIOSTOMUM (Willach) AND SOME REMARKS ON THE CLASSIFICATION OF THE STRONGYLIDAE
}

BY

\author{
J. E. W. IHLE \\ UTRECHT.
}

(With 5 figures)

When the editors of this memorial volume invited me to write a contribution, I was glad to have an opportunity to express my regard and esteem for Prof. MAX WEBER whom I have the privilege to reckon amongst my teachers. When I was a student and afterwards, when I examined material, collected by the Siboga-Expedition, which he led with so much success and the results of which are so exquisitely published, I had plenty of occasion to appreciate WEBER as man, professor and investigator.

My colleague, Prof. J. PoEls, director of the Rijksseruminrichting at Rotterdam, provided me with the material for this investigation: 5 worms ( $2 \sigma^{7} \sigma^{7}, 3$ immature $\left.Q P\right)$, found in nodules of the wall of the intestine of an orang-outan. They proved to belong to Oesophagostomum apiostomum (Willach), a species of which it is not superfluous to give a somewhat detailed description.

This species was described by Willach (1891) and later on by RaIlliet \& Henry (1906). WALKER (1913) studied the free living larval stages. It is closely related to O. Brumpti.

Description. When fixed, the worms have contracted strongly and hence they are coiled. The $\sigma^{7} \sigma^{7}$ are 10-12.8 mm. long; the longest, least contracted $\sigma^{7}$ has a maximum thickness of $425 \mu$, the other one a thickness of $565 \mu$. The $O O$ are 11.5-15 mm. long; the longest, least contracted $Q$ has a maximum thickness of $530 \mu$, the others a thickness of $650-665 \mu$. These measurements agree with those of Willach and Railliet \& HenRy ( $\sigma^{7}$ long $10-12.5 \mathrm{~mm}$., broad $400 \mu$, o long 12-16 mm., broad $450 \mu$ ).

In the least contracted $\sigma^{\gamma}$ the cuticular striae are $16-17 \mu$ distant from each other, in the least contracted $q$ they are $12.5 \%$ distant from each other. According to RaIlLIET \& HenRY this distance is $12-14 \mu$. Behind the mouth-collar a distinct cuticular swelling (vésicule céphalique RAILliET) is present. In the $\sigma^{7} \sigma^{7}$ the transverse cervical groove (fente ventrale RAILLIET) is $262-270 \mu$, in the $\$ ? 308 \mu$ from the anterior extremity; according to RAILliET \& HENRY this distance is $250-275 \mu$. Behind the cervical groove the cuticle is also somewhat swollen; this swelling disappears backwards, before the posterior extremity of the oesophagus is reached.

The mouth-collar is well developed (fig. 1). Its outer margin does not ascend so steeply from the circular groove behind it as in Railliet \& Henry's figure (1912, pl. 22, fig. 2, 3) of $O$. Brumpti. The two lateral papillae scarcely protrude. The 4 submedian papillae do not agree with the figure of WiLlach. They

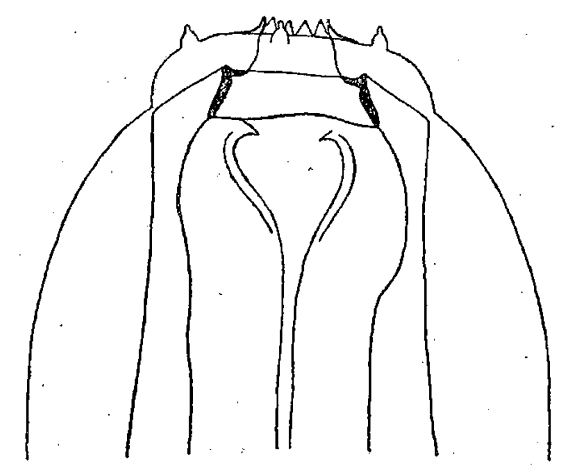

Fig. 1. Anterior extremity with mouth-collar, mouth-capsule and oesophageal funnel. $\times 270\left(\times \frac{3}{4}\right)$. are rather short and consist of two parts, the proximal one being the longest and the distal one appearing as a small appendage of the proximal part. The latter tapers in distal direction. According to the figure of RaILliet \& Henry (l. c.) this part has a cylindrical shape in O. Brumpti. 
In one of the species examined the external leaf-crown consists of 13 elements, which, seen from before, possess rounded tips and limit a circular opening. RAILlIET \& HENRY state: "coronule externe paraissant formée d'une dizaine de dents". The mouth-capsule has the shape of a truncated cone. Its anterior margin forms a short circular fold, protruding towards the body-axis (fig. 1). For this reason the diameter of the entrance to the cavity of the mouth-capsule is only $45-49 \mu$, the oral diameter of the mouth-capsule, its wall included, being $60-70 \mu$. The caudal diameter of the mouth-capsule is $78-82 \mu$, its length is $21 \mu$. According to RAILLIET \& HENRY the anterior diameter averages $48 \mu$, the posterior diameter $65 \mu$, the length $20 \mu$. An internal leaf-crown seems to be absent. The posterior margin of the mouth-capsule is provided with 3 shallow incisions, while in $O$. Brumpti this margin shows 3 incisions reaching the middle of the mouth-capsule.

The oesophageal funnel is well developed; its cuticular wall possesses a small pointed nodule in the dorsal mid-line and latero-ventrally near the posterior margin of the mouth-capsule. This nodule is also mentioned by Railliet \& Henry. O. Brumpti possesses curved teeth at these places.

The length of the oesophagus is in the $\sigma^{7} 615 \mu$, in the $ᄋ 685-720 \mu$, according to RAILliEt $\&$ HENRY 550-600 $\mu$. The anterior part, containing the oesophageal funnel, is slightly thicker than the following part. Its minimum thickness is $75 \mu$. Close in front of the posterior extremity the oesophagus has its maximum thickness $\left(170 \mu\right.$ in the $\sigma^{7}, 165-170 \mu$ in the $ᄋ$, according to RAILLIET \& HENRY $165 \mu)$. The wall of the mesenteron is pigmented, which characteristic is also mentioned by Willach and Railliet \& HenRy.

The median lobe of the bursa copulatrix (fig. 2-4) is somewhat emarginate in the median plane, does not protrude and is separated by a shallow incision from each lateral lobe. The rays have

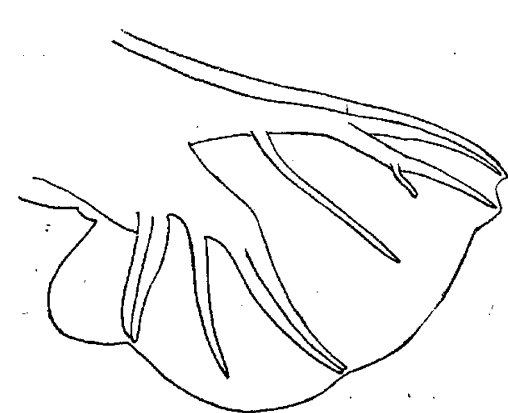

Fig. 2. Bursa copulatrix, lateral view. $\times 110\left(\times \frac{3}{4}\right)$.

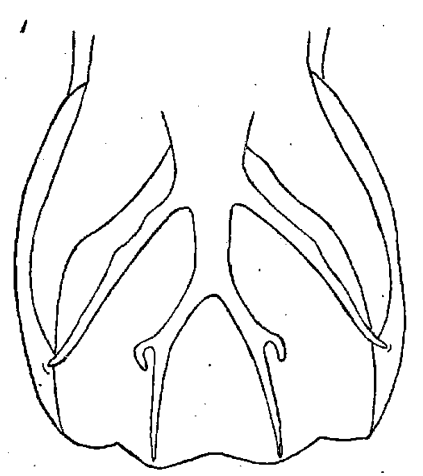

Fig. 3. Bursa copulatrix, dorsal view. $\times 122\left(\times \frac{3}{4}\right)$.

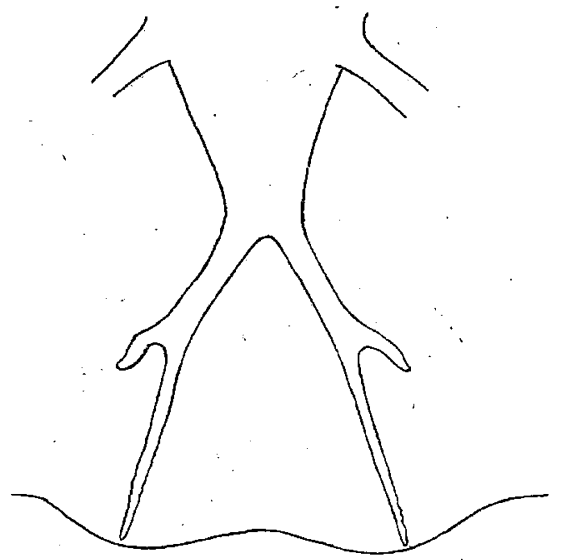

Fig. 4. Dorsal ray of the bursa copulatrix, spread out. $\times 270\left(\times \frac{2}{3}\right)$.

a course typical of Oesophagostomum. So each ray $\mathrm{D}$ divides into a short lateral ray $\mathrm{D}_{1}$ and a medial ray $\mathrm{D}_{3}$, which is the continuation of $\mathrm{D}^{1}$ ). $\mathrm{D}_{\theta}$ has a length of $96 \mu$, measured from the origin of the externo-dorsal ray to the bifurcation. $\mathrm{D}$ is $82 \mu$ long, measured from the bifurcation of $\mathrm{D}_{0}$ to the branching of $\mathrm{D}$ in $\mathrm{D}_{1}$ and $\mathrm{D}_{3} . \mathrm{D}_{1}$ is $29 \mu$ and $\mathrm{D}_{3} 123 \mu$ long. $\mathrm{D}_{1}$ is directed backwards and somewhat exteriorly. The externo-dorsal ray ends at a rather large distance from the border of the bursa. From the common stem of the lateral rays the externo-lateral ray first comes off and ends at a rather long distance from the border of the bursa, while the medio- and postero-lateral rays, which run parallel, terminate, at a short distance from this border. The ventral rays end quite near to the border of the bursa.

In one of the $2 \sigma^{3} \sigma^{3}$ the spicules protrude from the cloacal opening and are somewhat unequal

1) I use a nomenclature previously applied by me $(1921, \mathrm{p}, 401)$, in which the median stem of the dorsal ray is called $\mathrm{D}_{0}$. This one bifurcates into two branches $(D)$ which divide into rays called $D_{1}, D_{2}$ and $D_{3}$ from before backwards. In Oesophagostomum $\mathrm{D}_{2}$ is generally lacking apparently. Behind $\mathrm{D}_{1}$ a short lateral side branch can be present, which is found by CL. LANE (1917, pl. 35) in O. radiatum trifurcatum and sometimes in $O$. venulosum and which may be interpreted as $\mathrm{D}_{2} . \mathrm{D}_{3}$ of Oesophagostomum then agrees with $\mathrm{D}_{3}$ of Cylicostomum and allied genera, this ray being the direct continuation of $\mathrm{D}$ in these cases. Apparently $\mathrm{D}_{2}$ is disappearing in Oesophagostomum. 
in length, resp. 1350 and $1285 \mu$. The distal ends, situated close to each other, are pointed. According to RAILLIET \& HENRY the length of the spicula amounts to $1250-1275 \mu$.

The posterior extremity of the $O$ (fig. 5) agrees with that of $O$. Brumpti. Already before the vulva the body tapers to end at the level of the anus in a point not always sharply marked off. The vagina is long and directed longitudinally. The distance between vulva and anus is $205-240 \mu$; the distance between the anus and the tip of the tail is $205-210 \mu$. According to Railliet \& HENRY these measures are resp. $240 \mu$ and $180 \mu$; according to Willach 100 and $200 \mu$. In the specimens examined by me vulva and anus are not salient, contrary to the statements of Railliet \& HenRy. Willa.CH only mentions that the anus protrudes, so. that this characteristic is not of much systematic- value.

Geographical distribution. O. apiostomum was described by WILLACH in Macacus cynomolgus and found several times by. WEINBERG (1909) in $M$. cynomolgus and $M$. sinicus. The specimens collected by him were examined by RAILlIET \& HENRY. This species is of common occurrence in the Philippine Islands according to WALKER (1913, p. 501). LEIPER (1911, p. $116 ; 1913$, p. 274) thinks that this species occurs in negroes in Northern Nigeria. The specimens examined by LEIPER were thought to be an independant species by RaILlieT \& HenRY (BRUMPT, 1913, p. 456). I agree with this opinion as LEIPER's specimens differ too much from the description of RAILLIET \& HENRY and from that given above in shape and measurements of the mouth-capsule, the height of the mouth-collar, the length of the spi-

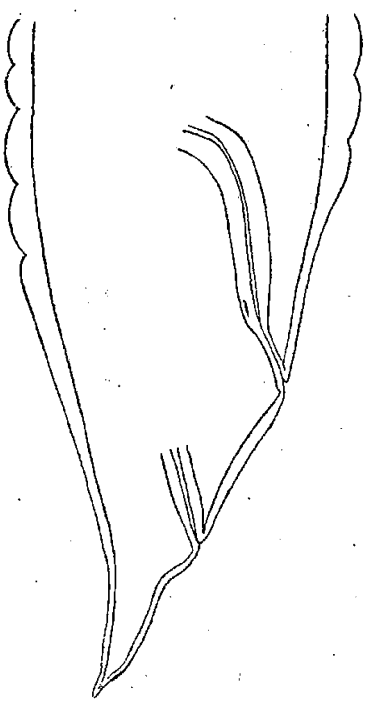

Fig. 5. Posterior extremity of $P$, lateral view, with vulva and anus. $\times 122\left(\times \frac{2}{3}\right)$ cules etc. CL. LANE (1916, p. 12) leaves this question undecided. Apart from LeIPER's observation $O$. apiostomum is found only in Asiatic monkeys up to now. This species was not yet found in the orang-outan.

The Oesophagostomum-s pecies occurring in Primates. Besides O.apiostomum the following species are found in man and monkeys (RaIlliet \& HenRY, 1906, p. 448; 1909, p. 168; STILES \& HASSELl, 1920, p. 611).

O. Brumpti Railliet et Henry, in man, in Asiatic and African monkeys (RAIlliET \& HenRY, 1912, p. 567).

O. Blanchardi Railliet et Henry, in orang-outan, Borneo (Railliet \& HenRY, 1912, p. 572, note).

O. stephanostomum Stossich, in gorilla, Africa (Stossich, 1904, p. 2; RaILliet \& Henry, 1912, p. 572).

$O$. stephanostomum var. dentigera (Railliet et Henry) $=O$. dentigerum Railliet et Henry, in chimpanzee, Afrika (RAIlliet \& HenRY, 1906, p. 448; 1912, p. 572).

O. stephanostomum var. Thomasi Railliet et Henry, in man, Brazil (RaILliet \& HenRY, 1912, p. 570).

O. pachycephalum Molin, in Cercopithecus, Africa (Molin, 1861, p. 450; BRUMPT, 1913, p. 455).

The following species are to be regarded as species inquirendae.

O. aculeatum (v. Linstow), in Macacus cynomolgus, Asia (v: Linstow, 1879, p. 333).

O. attenuatum (Leidy), in Cynocephalus porcarius, Africa (LEIDY, 1904, p. 100).

O. bifurcum (Creplin), in Cercopithecus patos, Africa (CREPLIN, 1849, p. 54; 1850, p. 480; DIESING, 1861, p. 722 ).

O. ovatum (v. Linstow), in Hylobates syndactylus and agilis, Sumatra (H. SMIDT, 1906, p. 646). This species is perhaps identical with O. apiostomum.

Key to the well-known species of Oesophagostomum in Primates.

1. mouth-collar spherically inflated '), o $\sigma^{7} 11.5-21 \mathrm{~mm}$., \& $15-27 \mathrm{~mm}$. long . O. pachycephalum. mouth-collar high but not spherical. . . . . . . . . . . . . 2.

2. elements of the external leaf-crown numerous (ca. 38), mouth-capsule nearly cylindrical . . . . . . . . . . . . . . . . . . . . 3. the elements of the external leaf-crown number less than 20. . . . . 4.

1) "Caput epidermide sphaerice inflata" (Molin, 1861, p. 450). 
3. ray $\mathrm{D}_{1}$ directed obliquely to the exterior ... . . . . . . . . . O. stephanostomum ray $\mathrm{D}_{1}$ directed backwards, length of $\sigma^{r} 18-22 \mathrm{~mm}$., of o $20-26 \mathrm{~mm}$. . O. steph. var. dentigera. ray $D_{1}$ directed obliquely to the interior, length of $\sigma^{7} 17-22 \mathrm{~mm}$. , of $\mathrm{t}$ 16-20 mm. . . . . . . . . . . . . . . . . . . . O. steph var. Thomasi.

4. external leaf-crown consists of 16 elements, spicules up to $1825 \mu$ long. O. Blanchardi. external leaf-crown consists of 10-13 elements, spicules up to $1350 \mu$ long, the mouth-capsule has the shape of a truncated cone. . . . . . 5 .

5 . length of $\sigma^{7} 6.7-11 \mathrm{~mm}$., of $O$ up to $12.5 \mathrm{~mm}$. 1), anterior diameter of the mouth-capsule averages $35 \mu$, posterior diameter $45 \mu$, spicules $900-1080 \mu$ in length $\left.{ }^{2}\right) . \mathrm{D}_{1}$ is directed backwards and somewhat to the interior . . length of $\sigma^{7} 10-12.8 \mathrm{~mm}$., of 0 11.5-16 mm., anterior diameter of the mouth-capsule $60-70 \mu$, posterior diameter $78-82 \mu$, spicules 1250 $1350 \mu$ in length. $\mathrm{D}_{1}$ is directed backwards and somewhat to the exterior. O. apiostomum.

Subge nu s Conoweberia (n. s u b g.). Railliet \& Henry (1913, p. 507 ; Railliet, Henry \& Bauche, 1919 , p. 332) have divided the Oesophayostomum-species of the Artiodactyla into 3 subgenera. O. apiostomum and $O$. Brumpti, closely related to each other, cannot be grouped in one of these subgenera, so that a new subgenus may be created for these species, which in honour of MAX WEBER may be called Conoweberia. This name also points to the shape of the mouth-capsule which is a truncated cone. The systematic place of the other Oesophagostomum-species occurring in Primates I leave undecided.

The characteristics of the new subgenus of which O. apiostomum forms the type, are as follows:

Cuticle of neck inflated between the mouth-collar and the cervical-groove. Cervical papillae close behind the middle of the oesophagus. No lateral cuticular membranes. The mouth-capsule has the shape of a truncated cone. Oesophageal funnel with 3 teeth behind the mouth-capsule. Vagina long, from the vulva directed to the front.

The systematic place of the genus Oesophagostomum and the classification of the Strongylidae. Classifying the Strongylidae Railliet \& Henry (1912, p. 564; Railliet, 1916, p. 518) emphasize the structure of the bursa. LEIPER $(1908$, p. $190 ; 1913$, p. 276) does not agree with the opinion of the famous French authors and lays stress upon the importance of the structure of the mouth and mouth-capsule for taxonomic purposes. In the family of the Strongylidae LEIPER distinguishes amongst others the subfamilies Strongylinae (mouth with external leaf-crown) and Ancylostominae (mouth-capsule with teeth or cutting plates). CL. LANE (1917, p. 423), Travassos (1919, p. 65) and myself (in Sluiter, Swellengrebel \& IHLe, 1922) have followed this classification. Hall (1916, p. 119) is satisfied neither with RAILLIET \& HENRY's arrangement nor with that of LEIPER.

RAILliet (1916, p. 518) writes in support of his opinion: „HALL critique notre classification des Strongylidés parce qu'elle sépare des formes à bouche semblable; je ne crois cependant pas qu'on puisse, nier que les caractères tirés de la bourse caudale (caractères sexuels secondaires) l'emportent sur ceux que fournit la bouche (caractères d'adaption)". I do not believe that we can consider the characteristics of mouth and mouth-capsule simply "caractères d'adaption”, as the very uniform conditions of existence in the intestine of mammals could hardly produce the manifold and divergent structures of the mouth and mouth-capsule of the Strongylidae. On the other hand we see that some genera (Triodontophorus and Ternidens, LEIPER, 1913, p. 276) agree in a number of main points of the body-structure, but differ especially in the course of the rays of the bursa, this being a strong argument not to attribute too much systematic importance to the structure of the bursa.

RAILLIET (1916) places Oesophagostomum in the subfamily of the Oesophagostominae (formerly (1912, 1913) tribus of the Oesophagostomeae); moreover the genera Chabertia, Ternidens, Agriostomum and Bourgelatia (RAIlliet, HenRY \& BAUChe, 1919) are considered to belong to this subfamily. With LEIPER (1913, p. 277) I believe that we have to do with a heterogeneous group. Agriostomum belongs

1) According to ELDERS $\left(1917\right.$, p. 172, 173) the length of a $\sigma^{7}$ measured by him amounts to $12 \mathrm{~mm}$., of a $ᄋ$ to $14 \mathrm{~mm}$., but it is not certain whether the specimens examined by him belong to $O$. Brumpti or to O. apiostomum.

2) In specimens, considered to belong to O. Brumpti by H. J. SMIT (1919) (from a monkey which died on Java) the length of the spicula amounts to $1300 \mu$. 
to LeIPER's Ancylostominae; Chabertia differs in a mouth-opening which faces antero-ventrally; Ternidens is closely related to Triodontophorus; to include Bourgelatia in the Oesophagostomeae RaILliET, HENRY \& BAUCHE (1919, p. 325) had to modify their diagnosis of this group.

It does not seem advisable to divide LEIPER's Strongylinae into tribus, because the relations between the genera, belonging to this group, are very intricate, so that some of these genera agree with one genus in a certain group of characteristics (e.g. mouth and mouth-capsule), while they agree with a totally different genus in another group of characteristics (e. g. bursa).

For this reason, even after separating all genera without exterior leaf-crown, we cannot maintain RAILliET's groups: Strongyleae, Oesophagostomeae and Cylicostomeae (= Trichonemeae) as tribes of LEIPER's Strongylinae. RAILLIET's classification is based on the course of the rays of the bursa and on the position of vulva and uteri. Some differences between RaILLIET's groups appear to be not well defined, others to be of slight systematic value. E. g. in some cases it is more or less arbitrary whether the externo-dorsal ray is considered to originate independently or to originate together with the dorsal ray, which characteristic forms a difference between Strongyleae and Cylicostomeae. E. g. in the genus Bourgelatia, considered to belong to the Oesophagostomeae, there is a distinct space between the medioand postero-lateral ray (RAilliet, HenRY \& Bauche, 1919, p. 325), which is absent in the other Oesophagostomeae and present in Strongyleae and Cylicostomeae. The splitting up of the ray D in 2 or 3 branches, which characteristic is important in RAILLIET's taxonomy, is of little value, as e.g. CL. LANE (1917, p. 426) described an Oesophagostomum radiatum trifurcatum, in which ray D possesses 3 sidebrances, while the typical Oesophagostomeae possess only 2 sidebranches here. In connection with this CL. LANE (1914, pl. 52, fig. 19-21; 1917, p. 430) points to the fact that in Decrusia additicia ray $D_{0}$ bears 4 or 6 branchings at its extremity (ray $D$ is lacking). Neither must too much systematic value be attributed to the course of the uteri. Their course - whether parallel or opposite - is connected with the situation of the vulva, which is very variable and which can be inconstant even in one and the same species (e.g. Physocephalus sexalatus, cf. Seurat, 1920, p. 69).

Neither is TRAvassos' (1919, p. 65) division of LeIPER's Strongylinae into two tribes satisfactory. He distinguishes: Strongyleae (the longitudinal axis of the mouth-capsule is straight) and Ransomeae (the longitudinal axis of the mouth-capsule is curved). However, in the latter tribe in the genera Ransomus and Chabertia the mouth-opening is obliquely directed to :he ventral side, in Choniangium obliquely to the dorsal side. The structure of the bursa in Choniangium also differs from that of Chabertia and Ransomus in many respects.

Utrecht, April 1922. 


\section{LITERATURE.}

Brumpt, E. 1913. Précis de parasitologie. 2me éd. Paris.

CREPLIN, F. 1849. Nachträge zu Gurlt's Verzeichnisse der Thiere, in welchen Endozoen gefunden worden sind. 3. Nachtrag. Arch. f. Naturgesch. 15. Jhrg. 1. Bd.

- 1850. Strongylus (Cercopitheci) bifurcus. Magaz. f. d. gesammte Thierheilk. Vol. 16.

DiEsinG, K. M. 1861. Revision der Nematoden. Sitzungsber. math.-naturwiss. Cl. K. Akad. Wiss. Wien. Vol. 42 (Jhrg. 1860).

ElDERS, C. 1917. Over oesophagostomiasis. Tijdschr. v. vergel. geneesk. Vol. 2.

HALL, M. C. 1916. Nematode parasites of Mammals of the order Rodentia, Lagomorpha and Hyracoidea. Proc. U. S. Nat. Mus. Vol. 50

IHLE, J. E. W. 1921. On the genus Cylicostomum. Ann. trop. med. parasit. Vol. 15.

LANE, CL. 1914. Bursate Nematodes from the Indian Elephant. Indian Journ. med. research. Vol. 2

- 1916. The correct names of the Helminths of man. Indian med. gazette. Vol. 51.

- 1917. Bunostomum Kashinathi and the Ancylostomidae. Indian Journ. med. research. Vol. 4.

LEIDY, J. 1904. Researches in helminthology and parasitology. Smith. misc. coll. Vol. 46.

LEIPER, R. T. 1908. An account of some Helminthes contained in Dr. Wenyon's collection from the Sudan. 3 Rep. of the Wellcome Research Laboratories at the Gordon Memorial College, Khartoum.

- - 1911. The occurrence of Oesophagostomum apiostomum as an intestinal parasite of man in Nigeria. Journ. trop. med. hyg. Vol. 14

- 1913. Observations on certain Helminths of man. Trans. soc. trop. med. hyg. Vol. 6 .

LiNSTow, v. 1879. Helminthologische Untersuchungen. Jahreshefte Ver. f. vaterländ. Naturk. Württemberg. Vol. 35

MoLIN, R. 1861. Il sottordine degli Acrofalli. Mem. R. Istituto Veneto di sc., lett. ed arti. Vol. 9.

RAILliET, A. 1916. Nematodes parasites des Rongeurs. Rec. méd. vétér. Vol. 92.

- \& Henry, A. 1906. Sur les Oesophagostomes des Primates. C. R. Soc. Biol. Vol. 60.

- 1909. Sur la classification des Strongylidae. II. Ankylostominae. C. R. Soc. Biol. Vol. 66.

- 1912. Les Oesophagostomiens parasites de l'homme. Arch. parasit. Vol. 14.

- 1913. Sur les Oesophagostomiens des Ruminants. Bull. soc. path. exot. Vol. 6.

—— \& BAuche, J. 1919. Un nouveau Strongylidé du porc. Bull. soc. path. exot. Vol. 12.

Seurat, L. G. 1920. Histoire naturelle des Nematodẹ de la Berbérie. $1^{\text {me }}$ part.

Sluiter, C. Ph., Swellengrebel, N. H. \& Ihle, J. E. W. 1922. De dierlijke parasieten van den mensch en van onze huisdieren. Amsterdam.

SMIDT, H. 1906. Ueber einen neuen, beim Gibbon gefundenen Strongylus (Strongylus ovatus v. Linstow). Centralbl. f. Bakt. 1. Abt. Orig. Vol. 41.

SmIT, H. J. 1919. Oesophagostomum Brumpti. Ned.-Ind. Bl. v. diergeneesk. en dierent. Vol. 31.

Stiles, Ch. W. and Hassall, A. 1920. Index-Catalogue of medical and veterinary zoology. Roundworms. U. S. Public Health Service. Hygienic Lab. Bull. 114.

Stossich, M. 1904. Sopra alcuni Nematodi. Annuar. mus. zool. r. univ. Napoli. N. S. Vol. 1, Nr. 15.

TRAVASSOS, L. 1919. Esboço de uma chave geral dos Nematodes parasitos. Rev. veter. zootechnia.

WALKER, E. L. The life history of Oesophagostomum apiostomum. I. Development outside of the host. Philippine Journ. of sc., sect. B, Vol. 8.

WeINBERG, M. Oesophagostomose des Anthropoïdes et des singes inférieurs. Arch. parasit. Vol. 13.

WILlACH, P. Sclerostoma apiostomum. nov. sp. Ein neuer und gefährlicher Parasit der Affen. Arch. f. wiss. prakt. Thierheilk. Vol. 17. 